\title{
Implementation of Social Protection Interventions in Africa. "The Trend in the Outcomes of Free Basic Education in Ghana, Malawi, Kenya and Uganda"
}

\author{
Joseph Kwasi Brenyah ${ }^{1,2, i}$ \\ ${ }^{1}$ Centre for Social Policy Studies, University of Ghana, Ghana \\ ${ }^{2}$ Department of Social Work, University of Wyoming, USA
}

Copyright $\mathrm{C} 2018$ by authors, all rights reserved. Author agrees that this article remains permanently open access under the terms of the Creative Commons Attribution License 4.0 International License

\begin{abstract}
Social protection interventions have been used as a poverty reduction strategy in many countries. Free Basic Education is one of the social protection interventions implemented in most developing countries. This review assessed the outcome of the implementation of Free Basic Education in Africa, using Ghana, Uganda, Kenya, and Malawi as a test case. Thirty-Seven (37) published documents were used for the study. The study is underpinned by Bagozzi's Goal Theory and Conceptualized with Knowledge Gaps and Knowledge Management Strategies. The study noted that, the Free Basic Education Policy has increased primary school net enrolment rates in these countries holding all other confounders constant. The study also revealed that, the implementation of the Free Basic Education Policy did not reduce educational expenditure as expected as school authorities continue to levy pupils. The objective of removing financial barriers was therefore not met, and the quality of teaching and learning delivery in most schools has fallen due to high pupils-teacher ratio and other implementation challenges. Based upon these findings, the study concluded that, there is the need for constant stakeholder interaction, efficient financial practices, fiscal space creation, provision of more educational infrastructure, recruitment of additional teachers, measures to ensure quality of teaching and learning delivery and effective monitoring of social protection intervention programmes in Africa.
\end{abstract}

Keywords Social Protection, Trend, Outcome, Free Basic Education, Ghana, Malawi, Kenya, Uganda

\section{Introduction}

Poverty reduction and welfare seem to be the global aspiration by bilateral and multilateral institutions. Best possible means of reducing poverty, vulnerability, and securing socio-economic development have been the focus of the international community. Development may be secured if some parameters are available to the people. Among such parameters are political freedom, provision of socio-economic facilities, promotion of transparent governance, provision of social opportunities and security [1]. One strategy of achieving these parameters was the implementation of Social Protection Floors (SPFs) by the international policy community ${ }^{[2]}$.

The SPFs may ensure food security, promote good health and education, provide safe water and shelter, as well as ensure income security through cash transfer ${ }^{[3,4]}$. These social protection floors (SPFs) were implemented through social protection interventions. Countries such as South Africa, Zambia, Mauritius, Ghana, Mexico, Brazil, Uganda, Malawi, Kenya and others have adopted some social protections interventions for their citizens. For instance South Africa implemented cash transfers (Child Support Grants, Disability Support Grants) and Universal Social Pension etc.). This idea of social protection floors promulgated the development of numerous policy documents that guided the implementation of social protection interventions.

For instance, Ghana developed the National Social Protection Strategy (NSPS) in 2007 as a framework for the implementation of about 44 social protection interventions. Some of these social protection interventions are; School Feeding Programme, the Free Compulsory Universal Basic Education (capitation grant), the National Health Insurance Scheme (NHIS), Free Maternal Care, Disability Funds, Cash Transfers, Metro Transport Services, Public Works Services, Contributory, and Non-Contributory Social Pensions.

Numerous writers have reviewed the various social protection intervention programmes implemented in different countries. This paper adds to the body of 
knowledge of reviews, by looking at the implementation of Free Basic Education as a social protection intervention in Ghana, Uganda, Malawi, and Kenya using the primary school net enrolment rates.

The study has become necessary as the knowledge of the implementations status, outcome, and challenges of Free Basic Education may inform policy.

\section{Objective of the Paper}

This paper assessed the trend in the outcomes of the implementation of Free Basic Education in African using Ghana, Malawi, Kenya, and Uganda.

\section{Methodology}

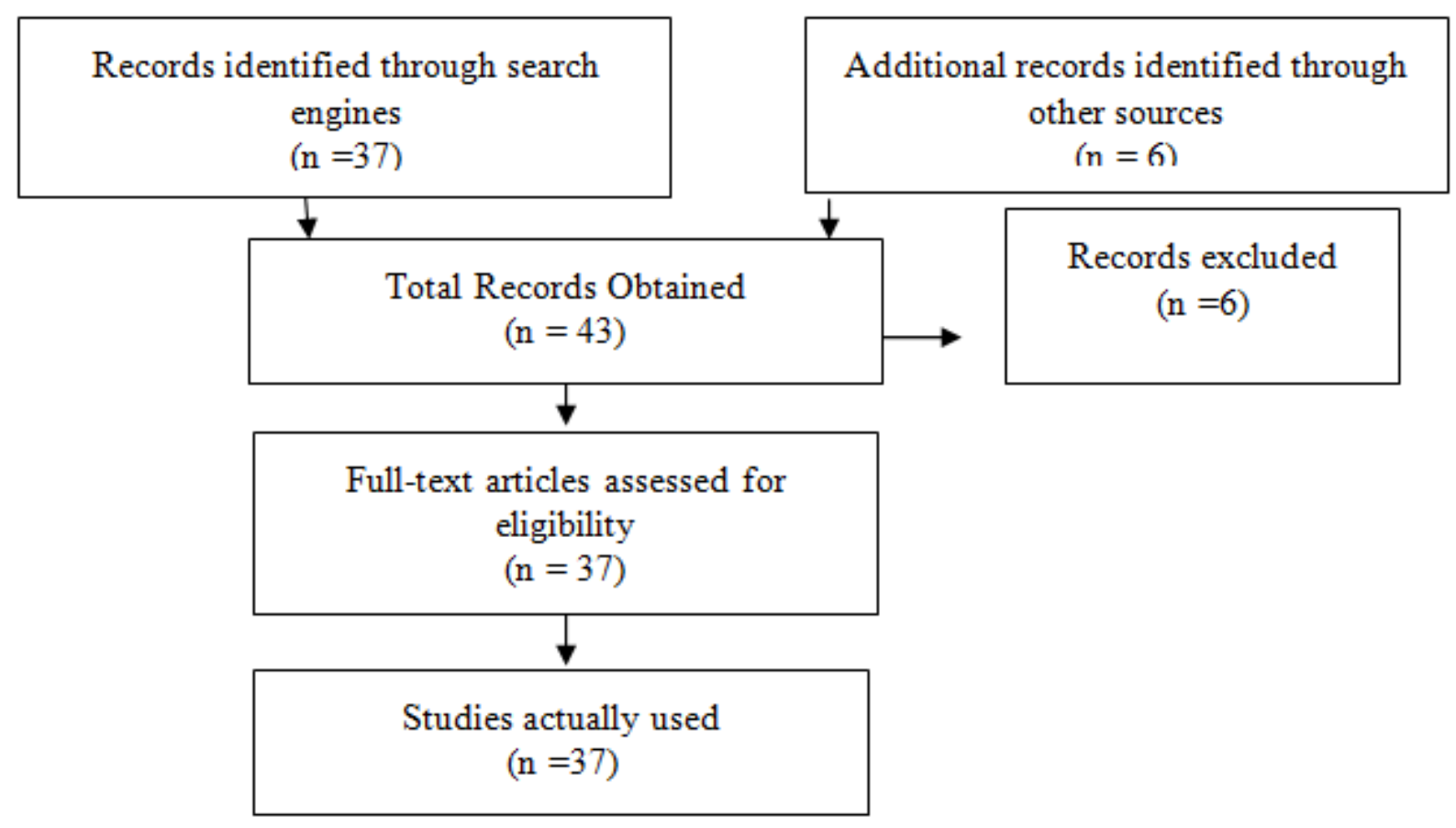

- The net enrolment rate is the enrolment of the official age-group for a given level of education (Pre-primary level, Primary level, Secondary level and Tertiary level) expressed as a percentage of the corresponding population.

- The outcome of an activity, procedure, or condition is the situation that exists at the end.

- A trend is the general tendency of a series of data points to move in a certain direction over time, denoted by a line or curve on a graph.

Forty-Three (43) articles were downloaded using the following online search engines: EBSCO Host, Science Direct, Oxford Journals, Cambridge Journals, Wiley online, UG Research, and other sources. The search terms were Social Protection AND Trend AND Outcome AND Free Basic Education AND Ghana AND Malawi AND Kenya AND Uganda. Based on the inclusion criteria, thirty-seven (37) articles were used for the study. Find below the flow chart of articles retrieved.

Figure 1. Flowchart Showing How Articles Were Retrieved 
This paper is a review of Free Basic Education in Africa. The paper is divided into eight (8) sections. These are introduction, objectives, methodology, theoretical and conceptual perspectives, Empirical perspectives, discussions and conclusion. The table below illustrates samples of the literature for the review:

Table 1. Sample of Some Literature on Free Basic Education

\begin{tabular}{|c|c|c|c|c|c|}
\hline No. & Author(s) & Study Title & $\begin{array}{l}\text { Methodology/ } \\
\text { Study Design }\end{array}$ & Participants & Main Findings \\
\hline 1 & JICA (2012) & $\begin{array}{l}\text { Basic Education Sector } \\
\text { Analysis Report, } \\
\text { Uganda }\end{array}$ & Report & Nation Wide & $\begin{array}{l}\text { The number of school children } \\
\text { attending primary education } \\
\text { increases by } 1.3 \text { times annually. }\end{array}$ \\
\hline 2 & Awoyemi. et. al (2011) & $\begin{array}{l}\text { Effects of Distance on } \\
\text { Utilization of Health } \\
\text { Care Services in Rural } \\
\text { Kogi in Nigeria }\end{array}$ & Survey & $\begin{array}{c}160 \text { rural } \\
\text { households \& } \\
60 \text { health care } \\
\text { providers }\end{array}$ & $\begin{array}{l}\text { Distance affects access to } \\
\text { socio-economic Services. }\end{array}$ \\
\hline 3 & Little W. A., 2010) & $\begin{array}{l}\text { Access to Basic } \\
\text { Education in Ghana: } \\
\text { Politics, Polices \& } \\
\text { Progress } \\
\end{array}$ & Document & Nation Wide & $\begin{array}{l}\text { Capitation grant has increased } \\
\text { access to basic education in Ghana. }\end{array}$ \\
\hline 4 & Abdul, et. al (2015) & $\begin{array}{l}\text { Analysis of School } \\
\text { Enrolment in Ghana: A } \\
\text { Sequential Approach }\end{array}$ & Review & $\begin{array}{l}\text { Secondary } \\
\text { School Students } \\
\text { and Primary } \\
\text { School pupils }\end{array}$ & $\begin{array}{l}\text { We find that household income has } \\
\text { a significant positive influence on } \\
\text { child school at secondary level. } \\
\text { Child work significantly hurts the } \\
\text { chances of passing the first } \\
\text { transition. }\end{array}$ \\
\hline 5 & Asante, C (2011) & $\begin{array}{l}\text { The Capitation Grant: } \\
\text { Impact on Enrolment } \\
\text { of Pupils in the Basic } \\
\text { Education Schools in } \\
\text { Ghana. A Case Study } \\
\text { of JHS in Sunyani } \\
\text { Municipality }\end{array}$ & Survey & $\begin{array}{l}100 \text { pupils from } \\
20 \text { schools }\end{array}$ & $\begin{array}{l}\text { Capitation grant has increased the } \\
\text { enrolment of pupils in the basic } \\
\text { schools. However, the ability of } \\
\text { the policy to enhance educational } \\
\text { quality is a problem. }\end{array}$ \\
\hline 6 & $\begin{array}{l}\text { Acheampong et. al } \\
\text { (2007) }\end{array}$ & $\begin{array}{l}\text { Access to Basic } \\
\text { Education in Ghana: } \\
\text { The Evidence and the } \\
\text { Issues. }\end{array}$ & Project Report & Survey & $\begin{array}{l}\text { The study identified children } \\
\text { excluded from accessing basic } \\
\text { education, identified the causes } \\
\text { and remedial measures. }\end{array}$ \\
\hline 7 & $\begin{array}{l}\text { Filmer \& Pritchette, } \\
\qquad(2004)\end{array}$ & $\begin{array}{l}\text { The effects of } \\
\text { households wealth on } \\
\text { educational attainment: } \\
\text { Evidence from } 35 \\
\text { Countries }\end{array}$ & $\begin{array}{l}44 \text { Demographic } \\
\text { and Health } \\
\text { Surveys from } 35 \\
\text { Countries }\end{array}$ & 35 Countries & $\begin{array}{l}\text { Enrolment profiles of poor differ } \\
\text { across Countries but fall into } \\
\text { distinctive Regional patterns. In } \\
\text { some poor Regions, the poor reach } \\
\text { nearly universal enrollment in the } \\
\text { first grade, but then drop out in } \\
\text { large numbers leading to low } \\
\text { educational attainment. }\end{array}$ \\
\hline 8 & Nishimura et al. (2009) & $\begin{array}{l}\text { A comparative } \\
\text { Analysis of Universal } \\
\text { Primary Educational } \\
\text { Policy in Ghana, } \\
\text { Kenya, Malawi and } \\
\text { Uganda }\end{array}$ & $\begin{array}{l}\text { Comparative } \\
\text { Analysis }\end{array}$ & 4 Countries & $\begin{array}{l}\text { When schools fees were abolished, } \\
\text { Over-age and under-age children } \\
\text { flocked into School. This resulted } \\
\text { in overcrowded classrooms which } \\
\text { led to low teacher motivation. }\end{array}$ \\
\hline 9 & Al-Samarrai (2003) & $\begin{array}{l}\text { Financing Primary } \\
\text { Education for All: } \\
\text { Public Expenditure \& } \\
\text { Education Outcome in } \\
\text { Africa. }\end{array}$ & Report & $\begin{array}{l}3 \text { Countries: } \\
\text { Botswana, } \\
\text { Uganda \& } \\
\text { Malawi }\end{array}$ & $\begin{array}{l}\text { Improving access to primary } \\
\text { education have predominantly } \\
\text { been a demand-side phenomenon } \\
\text { and improvements in education } \\
\text { outcomes will only be sustainable } \\
\text { if demand-side constraints to } \\
\text { primary schooling are tackled. }\end{array}$ \\
\hline
\end{tabular}

\section{Theoretical Perspective}

\subsection{Bagozzi's Goal Theory}

The study employed the Bagozzi's Goal Theory (BGT) to evaluation of social protection interventions. This theory was developed by Bagozzi in $1992^{[5]}$. The theory is built on motivational models by examining the motivational influences on goal intentions. Bagozzi asserted that, attitudes towards programme goals are three; (Attitude towards goal processes, attitude towards goal success and attitude towards goal failure) and all these are related to subjective norms and goal efficacy. This desire influences the formation of a goal intention. 
According to ${ }^{[5]}$ "the goal theory refers to processes that initiate and regulate the acts that lead to goal attainment. After the goal intention has been formed, three assessments decide the means of reaching the proposed goal: self-confidence, the likelihood of goal attainment and the perception of pleasantness or unpleasantness.

The theory espoused that, decisions regarding the means of action, planning, and control of goal-directed behavior and maintenance of commitment is crucial in programme implementation and evaluation. In addition, planning and control of goal-directed behaviour are functions of programme implementation ${ }^{[6]}$. Bagozzi's model has been widely applied to the field of social science, health psychology and consumer behaviour ${ }^{[7]}$. Aside from these, Bagozzi's goal theory was also applied in goal setting and goal-striving model to better understand and control the weight of United States ethnic group members ${ }^{[8]}$.

It could be realized that, all social protection interventions were developed with some underpinning goals. For instance, to ascertain the status of implementation of the Free Basic Education policy, the underpinning goals must be evaluated to determine whether the motive for that policy has been achieved or not.

\section{Conceptual Framework}

Conceptually, to be able to evaluate the social protection interventions, the goals for the interventions need to be evaluated. One way to carry out this is to identify the trend in outcomes and implementation gaps in the social protection interventions. The study therefore adopted and modified the concept of knowledge gaps developed by Triton, (2014) and applied it in social protection interventions analysis. Generally, this method involves
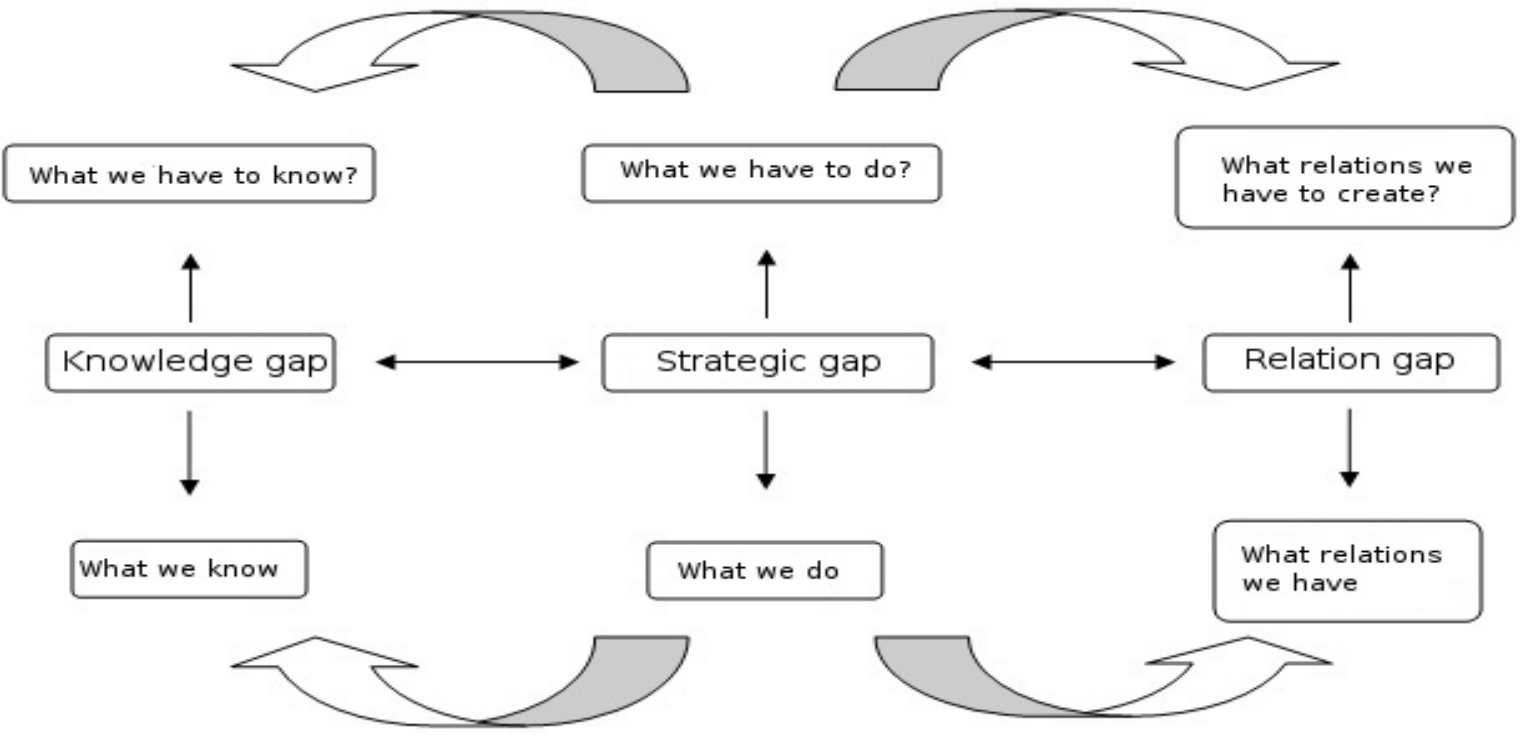

Source: Adopted from Triton, (2014).

Figure 2. Concept of knowledge Gaps and knowledge Management Strategies identifying gaps in knowledge and strategic relationships that are applicable to social protection programmes. Triton (2014) has revealed that, the gaps occur in three phases. Phase one (1), the knowledge gap occurs between what the programme implementers and beneficiaries needs to know, and what they actually know. Phase two (2), the Strategic gap-is the gap that occurs between the objectives of the social protection programmes and what programme implementers actually do to achieve them. Phase three (3), Relations gap - is the gap that exists between what the social protection interventions (Free Basic Education) must offer and what they actually offer as illustrated below.

\subsection{Empirical Analysis of the Free Basic Education}

There are growing consensus around the view that, social protection constitutes an effective response to poverty reduction and vulnerability in developing countries ${ }^{[2]}$. As mentioned earlier on, Ghana, has about forty-four (44) social protection interventions (2007) and less than fitften (15) are effectively working now. Some of the active social protection interventions are School Feeding Programme, Free Basic Education, Free Maternal Care, National Health Insurance, Cash Transfers, Public Works Programmes, and among others ${ }^{[3]}$.

It was believed that the successful implementation of these programmes would offer safety nets to the poor and reduce vulnerability.

Equally, Kenya has instituted social protection interventions such as Health Insurance Fund, Cash Transfers for Orphans and Older Persons, Hunger and Safety Nets Programmes, Urban Food Subsidy, among others ${ }^{[9]}$. Similarly, Universal Inputs Subsidies, Food Transfer Programmes, Public Works, School Feeding, Free Basic Education, Cash Transfers are social protection interventions implemented in Malawi ${ }^{[10]}$.

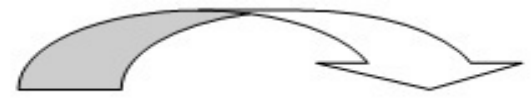
What relations we

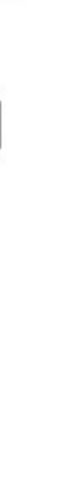


The social protection intervention programmes in Uganda are not different from Ghana, Kenya, and Malawi as stated earlier.

One reason for the implementation of social protection interventions by the governments of these countries is to satisfy the populace for them to achieve their political ambitions ${ }^{[11]}$. Contrary, another researcher also explained that, social protection interventions exist as an effort to address socio-economic inequalities within the system ${ }^{[12]}$. Therefore the implementation of social protection interventions exist due to thematically network of reasons aimed at achieving diverse welfare goals.

\subsection{Motivation for the Implementation of Free Basic Education Policy}

The Education For All campaign and the United Nations Millenium Development Goals (MDGs) were proposed as development tools for developing countries. The efforts in achieving MDGs 2; Accessibility to Basic Education had called for concerted efforts to coordinate in ensuring that all children of school going age were in school.

The Education for All or Universal Basic Education policy was introduced in 1990s. In Africa, the policy was named as Free Basic Education. Similarly, in Ghana the policy was named free Compulsory Universal Basic Education (fCUBE). The focus was to make education accessible to all by eradicating all barriers in basic schools in many countries in sub-Saharan Africa (SSA). Notable Countries with that agenda were Ghana, Kenya, Malawi, Uganda, among others ${ }^{[13,14]}$.

The services offered under the Free Basic Education were waiver of school fees (capitation grant in Ghana), supply of free text and exercise books, supply of school uniforms and supply of school footwear ${ }^{[15]}$. The principal motivation behind the Free Basic Education was to develop the human capital of the countries concerned. Mass education may also lead to improvement in productivity, the reduction of intergenerational poverty, improvement of preventive health care practices, empowerment of women, and close the inequality gap.

Indeed, the Universal Basic Education through capitation grants targeted at least 4 measures to ensure $100 \%$ compliance. These targets were to ensure that children who have never enrolled in school were enrolled, ensured zero drop out at the primary school level, ensured all children complete primary level and that no child dropped out during the JHS level ${ }^{[16]}$. The possibility of zero drop out at all levels was so much questionable and had generated a lot of dabates. There cannot be zero drop out when sub-Saharan African countries are living in abject poverty with more than two-thirds $\left({ }^{2} / 3\right)$ of the people living on less than $\$ 1.25$ a day ${ }^{[17]}$.

Many researchers have asserted that, poverty and household economic status are important determinant of children's ability to enroll and complete school ${ }^{[18,19]}$. For instance in Ghana, even though poverty levels have reduced from $43 \%$ in 1990 to about $28.5 \%$ in 2014 , completion of basic education is still a challenge. Going against all odds, how possible can there be complete eradication of school drop out at $28.5 \%$ poverty level? This dicsussion will be revisited in susequent sections to address issues of why poverty is a major cause of low educational level. This has been a worrying issue and many international bodies are funding programmes to reduce deprivations in education.

\subsection{Financing of Free Basic Education}

Developing countries are struggling to implement numerous social protection interventions, but the problem of funding keeps thwarting their efforts. This has resulted in various agencies funding different social protection interventions. For instance, major donors of the free Universal Education Policy are the World Bank and other subsidiary agencies. This is an intervention which countries incur huge cost to implement. According to Osei and colleagues ${ }^{[20]}$, in Ghana, expenditure on education reached $20 \%$ of the government budgets (approximately $5 \%$ of GDP) in 2005. In contrast to the above, before the commencement of the capitation grants in Ghana, government expenditure on education was about $3.8 \%$ of GDP in 1992 while the share of basic education in total education budget hovered around $70.2 \%$ between 1990 and $1994^{[21]}$. In 2010, the national educational budget was about $23 \%$, and basic education accounted for about $5.5 \%$, increasing to $8.2 \%$ in $2013^{[22]}$.

The story is not different in Uganda. Available research outcome has revealed that, $20 \%$ of Uganda's total public expenditure was spent on education in the mid-1990s, largely on primary education ${ }^{[23]}$. It was also noted that, the largest social intervention programme was capitation grant which covered about $13 \%$ of schools' non-wage expenditures from 1991-1995 ${ }^{[23]}$

Again, fees exemption in Uganda increased education expenditure to GDP from $1.6 \%$ to $4.0 \%$ and the segment of primary education expenditure increased from $40 \%$ to $70 \%$. The net multiplier effect was the increase in primary school enrolment from 3 million in 1996 to 7.5 million in 2007. Despite all these improvements in enrolment, only $22 \%$ of the children that enrolled in primary one in 1997 managed to survive to primary six in $2003^{[13]}$.

The implication is that, for Free Basic Education to be efficiently implemented, there is the need for huge capital base that merits high GDP ratio. However, in developing countries, due to structural challenges coupled with high Debt-GDP ratio, GDP is always low. The net effect is insufficient financing of social protection interventions programmes. In some instances, there are delayed payments to the schools. The current trend of events is the support from NGOs. For instance, in Ghana, NGOs like World Vision, Adventist Relief Agency, Plan Ghana and 
Action Aids have played various roles to ensure access to basic education.

\subsection{Challenges of the Free Basic Education Policy}

The Free Basic Education Policy had some challenges. Limited resources and lack of administrative capacity constrained the ability of the Ministry of Education to adequately implement the capitation grant policy ${ }^{[24]}$. Again, the limited resources have resulted in the inability of schools to maintain high level of enrolments and good performance at the schools.

Providing basic infrastructure to meet the increased enrolment had been a major challenge. Some schools are either under trees or operate the shift systems. Both conditions have their own negative implications for educational development in Africa.

Distance to school was also another challenge to the implementation of Free Basic Education in Africa. Educational facilities have to be geographically and financially accessible to the poor. However, in sub-Saharan Africa, geographical and financial accessibility have mostly impeded health care and education. For instance, in a study involving 160 rural households in Nigeria, it was revealed that, average distance to access social services such as health and education was $4.51 \mathrm{~km}$ with an average transportation fare of 345 Naira (Awoyemi, Obayelu, \& Opaluwa, 2011) ${ }^{[25]}$. Again, a study in Ghana stated that, average distance to access school was about $2.5 \mathrm{~km}$ with an average school expenses of GHC 62.06 per term, even though the Free Education Policy is in force ${ }^{[26,27]}$.

Logistical supplies, such as, text books, sports fees, printing fees, tables and chairs, among others take a longer time to be given by governments. This puts financial stress on school authorities compelling them to levy pupils directly or indirectly to keep the schools running. At times, there is a delay in disbursement of funds which distorts the schools activities and that negatively affects teaching and learning delivery.

All the above mentioned issues disrupted the enrolment drive of some schools. This disruption in enrolment drive was aggravated by child labor in some communities located around markets centres, mining, and cash-crop growing areas.
Again, the HIV/AIDS pandemic in sub-Saharan Africa, notably South Africa, Angola, and other East African countries also have negatively impact on the expected high enrolment rates in the implementation of Free Basic Education Policy. The HIV/AIDS pandemic has been an implementation challenge for almost all the social protection interventions. The pandemic had killed much of the labour force and leaving many orphans at the care of the aged ${ }^{[28]}$. The health condition above was made more pronounced by the high poverty profile in the sub-region. For instance, the Ghana Living Standards Survey (GLSS, R4) estimated $40 \%$ of Ghanaians as "poor" and not able to meet their basic needs. Again, about $14.7 \%$ of the population live in extreme poverty and suffers intergenerational poverty ${ }^{[29]}$. One strategy used by the poor households to gain income for livelihood has always been child labour, which opposes the enrolment drive intention of Free Basic Education. For instance in a study of household demand for schooling in Ghana, Awedoba et al. (2003) as cited by Acheampong ${ }^{[30]}$, found that economic shocks and minor changes in family conditions determine the degree to which children attend school or drop out momentarily or perpetually.

\subsection{Trend in Outcome of Free Basic Education in Ghana, Malawi, Kenya, and Uganda}

Despite the above implementation challenges, the Free Basic Education policy has positively impact on the educational sector of many countries holding all other confounding factors constant.

\subsection{Outcome of Free Basic Education in Ghana}

Firstly, the Free Basic Education recorded a spectacular trend in Ghana ${ }^{[31]}$. The trend in the net enrolment rates before the social protection intervention (Free Basic Education) decreased from $76 \%$ in 1998 to $61.9 \%$ in 2002. The early years of implementation of the Free Basic Education $(2003$, 2004) did not improve net enrolments rates. The impact of the Free Basic Education was realized in 2005 with an increase in NER of $65.5 \%$ through $91.1 \%$ in 2015 and marginal drop to $87.4 \%$ in 2016 as shown below: 
"The Trend in the Outcomes of Free Basic Education in Ghana, Malawi, Kenya and Uganda"

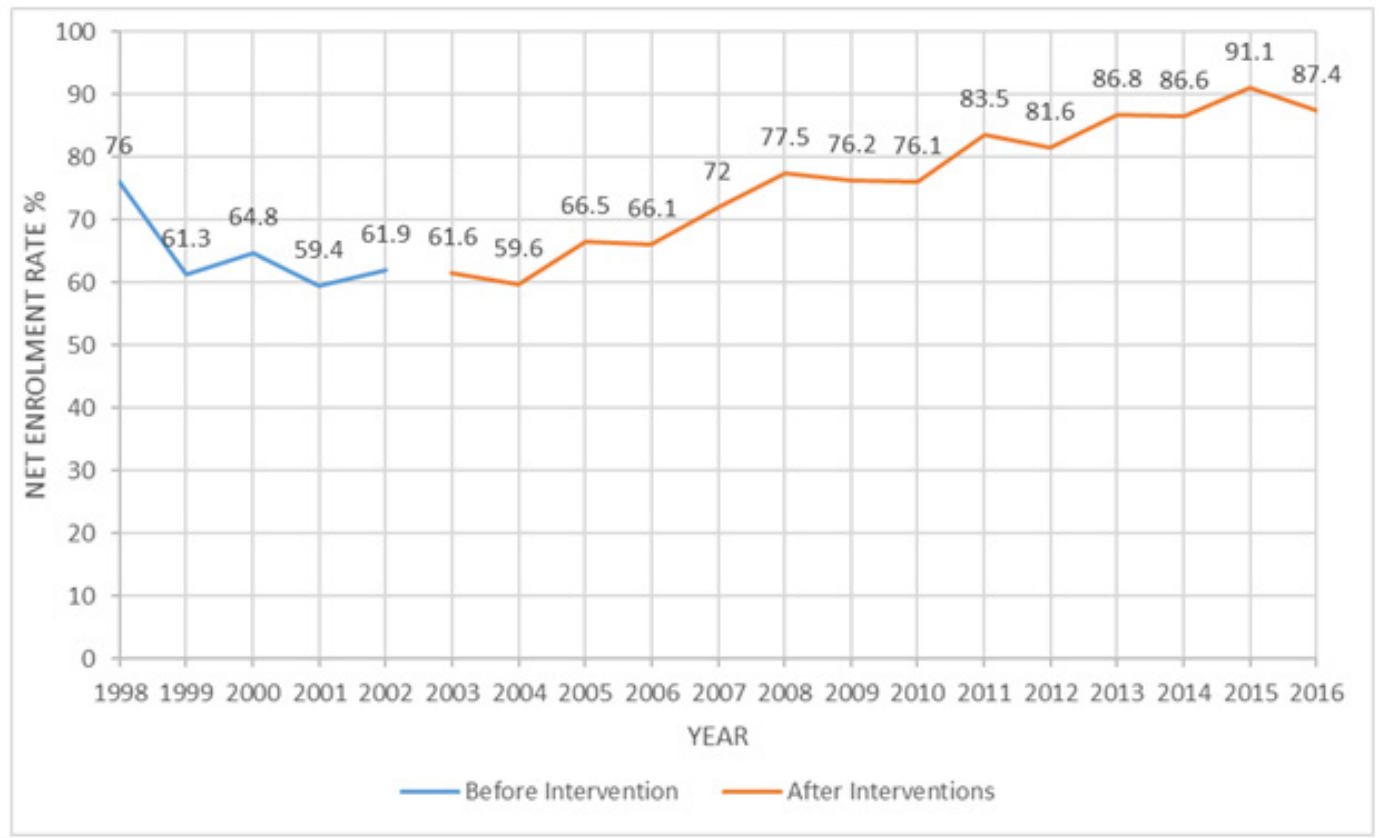

Source: Author's Own Construct: 2018

Figure 3. Primary School Net Enrolment Rate of Ghana from 1997-2016

\subsection{Outcome of Free Basic Education in Malawi}

In Malawi, it was noted that the net enrolment rates were already high prior to the introduction of the Free Basic Education. Since 2008, the net enrolment rate increased, attained a constant rate in 2012 and 2013 (96\%) each. The net enrolment fell in 2014 (94.6\%), increased in 2015 and 2016. It further increased appreciably in 2017 (97\%). Reasons were however, not found for the consistent decreases in net enrolment in those years (2014, 2015, and 2016). Even though the appreciable increases in net enrollments were cherished in 2017, it had some implications such as high pupils-teacher ratio of $83: 1$, instead of the previous $81: 1$. The implication was reduction in quality teaching and learning delivery ${ }^{[32]}$. The graph below illustrates the primary school NER of Malawi from 2002-2017.

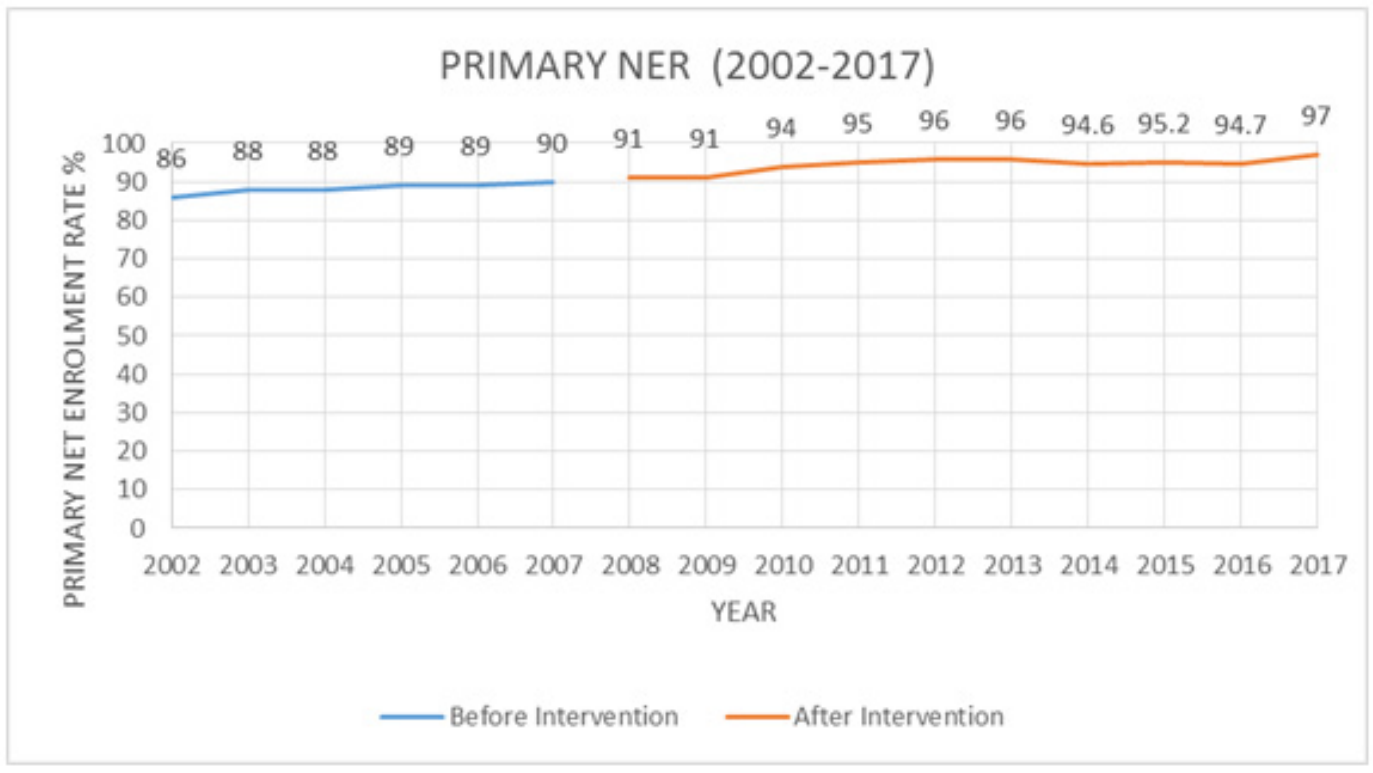

Source: Author's Own Construct, (2018)

Figure 4. Primary Net Enrolment Rate of Malawi (2002-2017) 


\subsection{Outcome of Free Basic Education in Kenya}

The Free Basic Education started in 2003 in Kenya. The case of Kenya, just like Ghana and unlike Malawi had low primary NER before the implementation of the Free Basic Education (62.3\% in 1999 to 62\% in 2002). However, after the implementation of the intervention, the country recorded increases in NER from $74.5 \%$ in 2003 , attained optimum of $86.3 \%$ in 2007 and thereafter recorded fluctuated deceased figures to $84.9 \%$ in $2012^{[31,33]}$ as shown below:

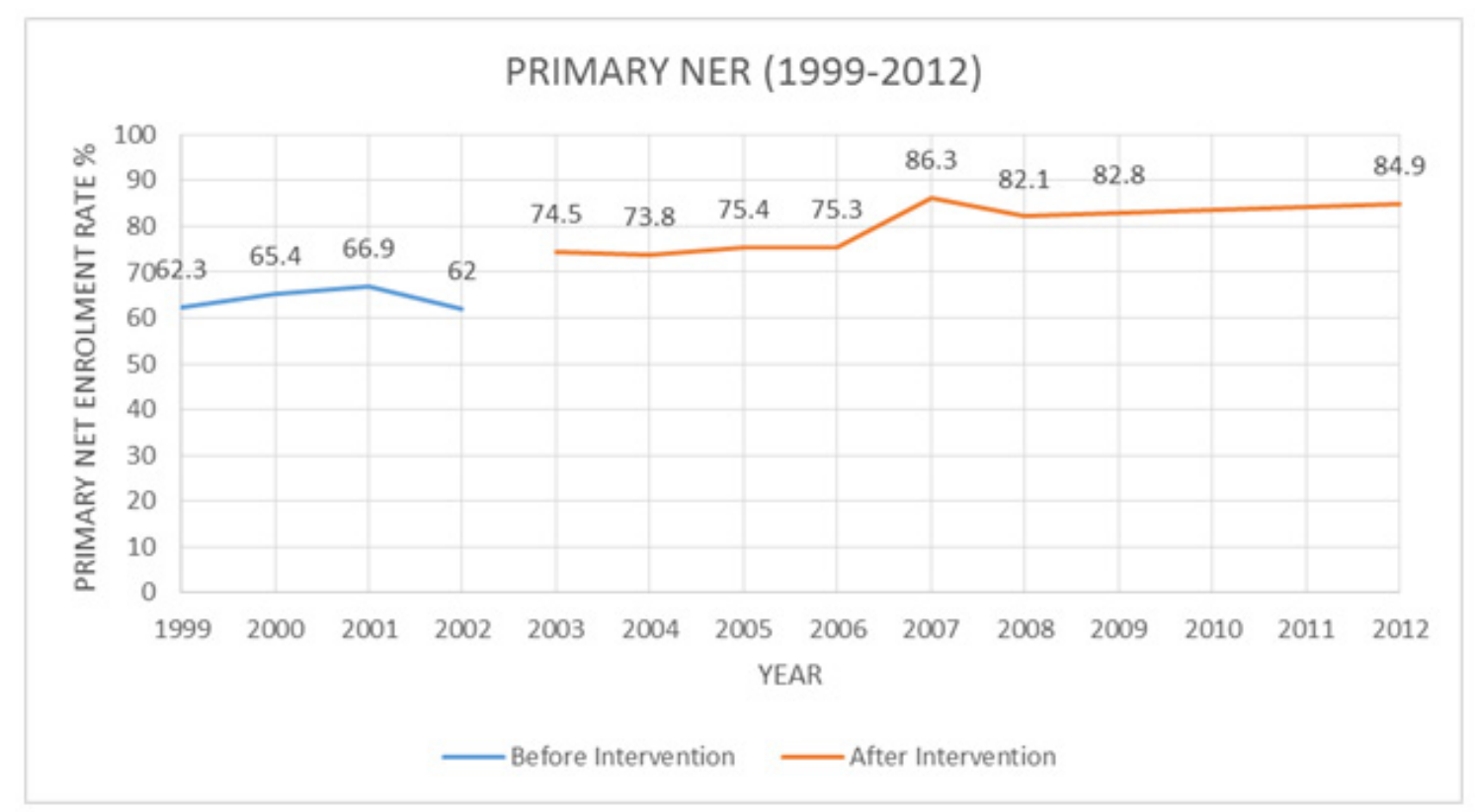

Source: Author's Own Construct, 2018

Figure 5. Primary Net Enrolment Rate of Kenya (1999-2012)

\subsection{Outcome of Free Basic Education in Uganda}

Uganda had poor NER before the implementation of the Free Basic Education. In 1989, the country recorded Primary NER of $53 \%$, increased to $54 \%$ in 1991 , decreased drastically to $45 \%$ in 1993 and increased to $53 \%$ in 1995 . The implementation of the Free Basic Education intervention increased Primary NER from 87\% in 1997 to $95 \%$ in 1998. Therefore after the intervention, the NER decreased to the $80 \%$ range and then increased again to $96 \%$ in $2017^{[34]}$ as illustrated below. The net multiplier effect of the intervention was seen clearly when primary school enrolment increased from 3 million in 1996 to 7.5 million in 2007.

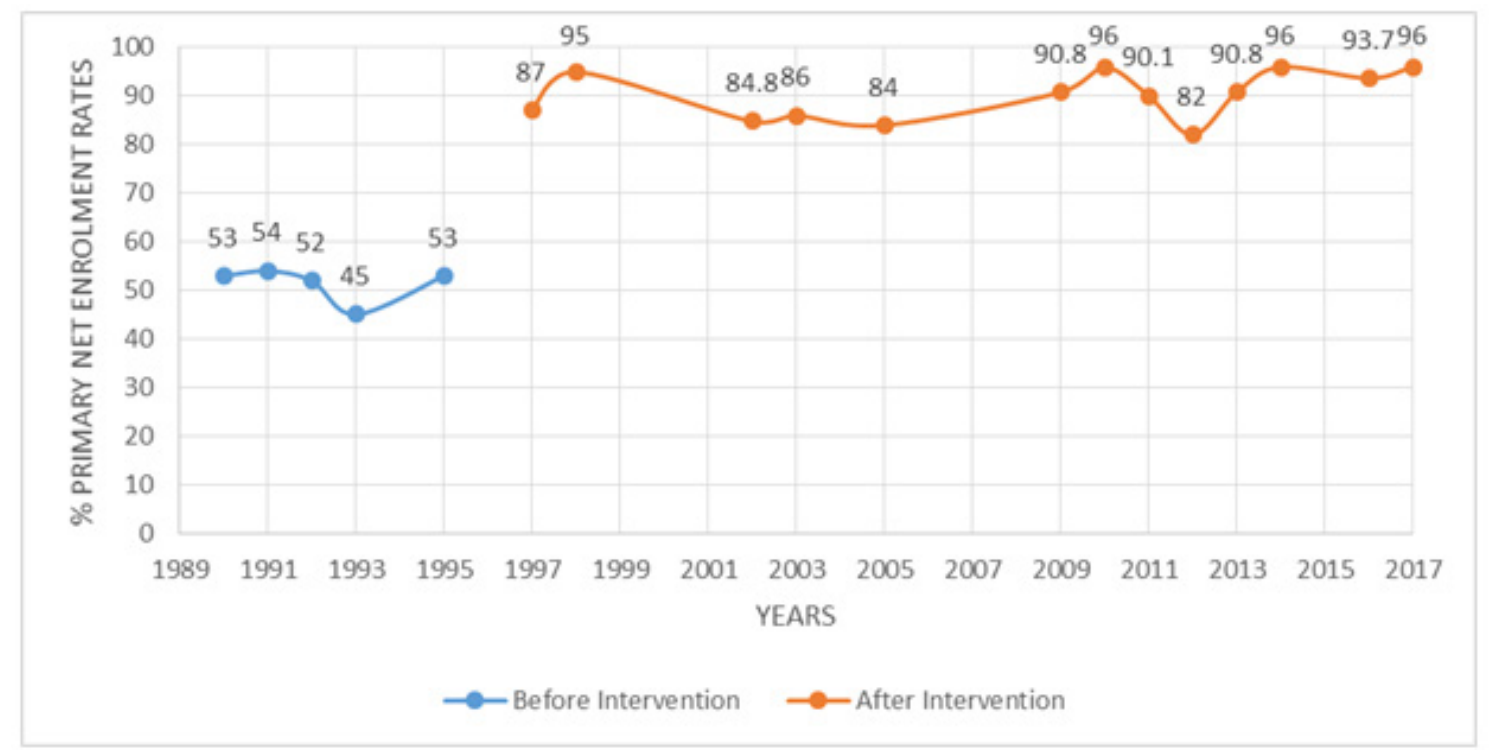

Source: Author's Construct, 2018

Figure 6. Primary Net Enrolment Rate of Uganda (1990-2017) 


\subsection{Comparative Analysis of Primary Net Enrolment Rates of Ghana, Malawi, Kenya, and Uganda before the Implementation of Free Basic Education}

In ranking the NER of these countries, it was realized that, Malawi was the best, followed by Kenya, Ghana, and Uganda as shown below:

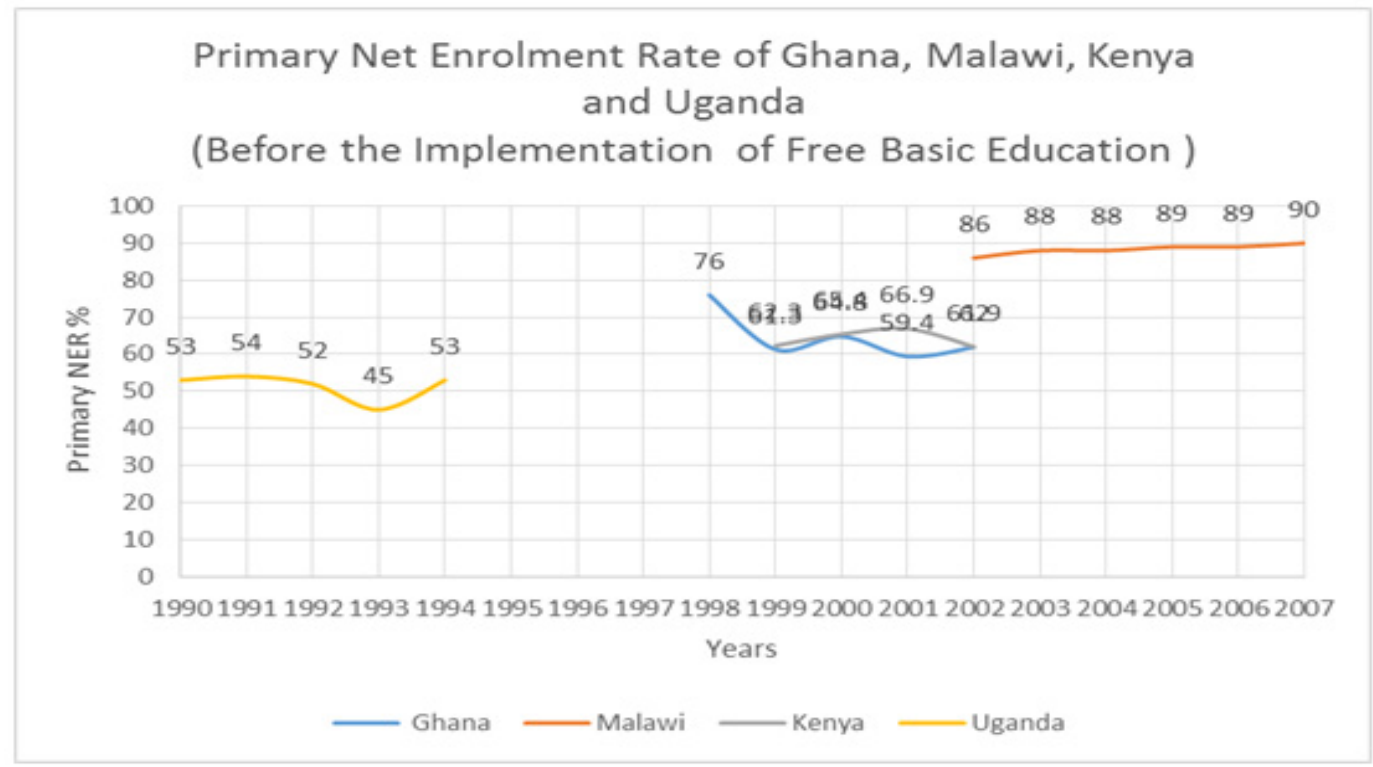

Sources: Author's Construct, 2018

Figure 7. Primary Net Enrolment Rate before the Implementation of Free Basic Education in Ghana, Malawi, Kenya, and Uganda

\subsection{Comparative Analysis of Primary Net Enrolment Rates of Ghana, Malawi, Kenya, and Uganda after the Implementation of Free Basic Education}

The Primary NER trend after the implementation of Free Basic Education in Ghana, Malawi, Kenya, and Uganda revealed that, Malawi had the highest Primary NER. It was also found that, the primary school NER of Uganda has improved than Ghana and Kenya after the implementation of the Free Basic Education as illustrated below:

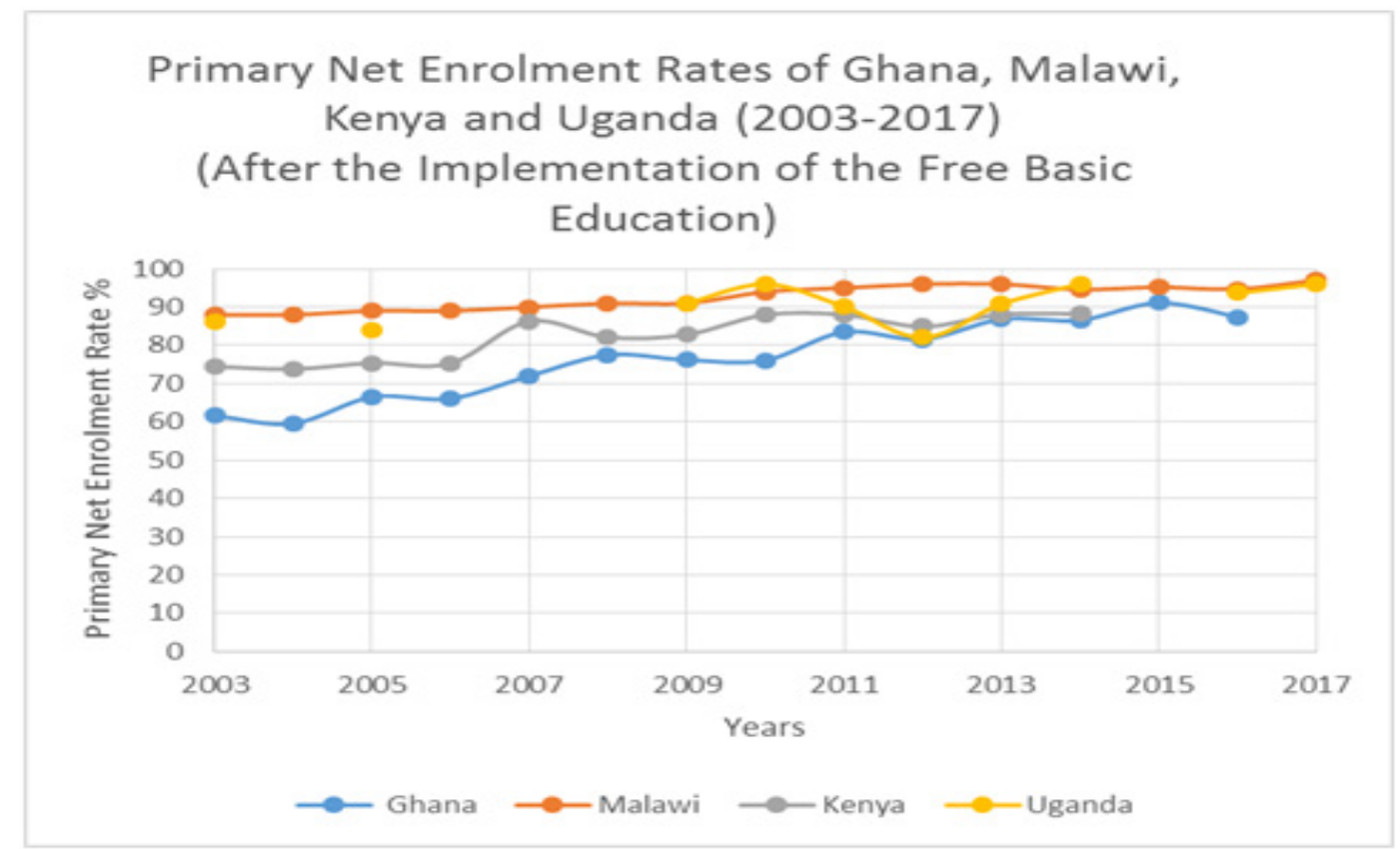

Source: Author's Own Construct, 2018

Figure 8. Primary Net Enrolment Rate after the Interventions in Ghana, Malawi, Kenya, and Uganda 


\section{Discussion}

From the above graphs, it was noted that, Ghana unlike Malawi had very low net enrolment rates before the implementation of the Free Basic Education interventions. After the implementation of the Free Basic Education, Ghana's net enrolment rates recorded fluctuating trends; either decreasing or increasing marginally across the years (2003-2016). This paper did not find out the reasons for the fluctuation trends. However, it was noted that the 2016 NER of $87.4 \%$, which is a decrease in net enrolment from $91.1 \%$ in 2015 , needs to be investigated.

In the case of Malawi, before the implementation of the Free Basic Education, the country had recorded increased NER from $86 \%$ in 2002 to $90 \%$ in 2007 . The introduction of the Free Basic Education further increased school enrolment rates from $91 \%$ in 2008 to $97 \%$ in $2017^{[35,32]}$.

From the earlier submissions, it was noted that, holding all confounders constant, the trend of net enrolment rates have increased in Kenya and that, the Free Basic Education has indeed been helpful. It was noticed that, Uganda had the lowest Primary NER prior to the implementation of the Free Basic Education. However, the outcome of the implementation of the Free Basic Education showed that, the Primary NER of Uganda (see figure 6) is much more better than Ghana (see figure 3) and Kenya (see figure 5) as shown above.

Even though the implementation of the Free Basic Education Policy was saddled with challenges such as limited resources, lack of administrative capacity, inadequate basic educational infrastructure and inadequate logistical supplies, the policy has successfully increased primary schools net enrolment rates in Africa.

\section{Conclusions}

In spite of the high costs of Free Basic Education policy, it has been demonstrated that, the programme has increased net enrolment rates in the four (4) countries. However, analysts believe that, the impact of the Free Basic Education on nets enrolment rates in Ghana was slower compared with similar programmes in Malawi, Kenya, and Uganda. This is because the grants never led to significant reduction in schooling costs to poorer households ${ }^{[36]}$. Some parents therefore make their children to sacrifice school and engage in income generating activities to support the family ${ }^{[30]}$.

Due to the implementation challenges facing the Free Basic Education policy, it is feared that, the countries in sub-Saharan Africa may not achieve the SDGs 4 (Quality Education). For instance, in Ghana, some schools are still operating under trees while others are on the shift system due to inadequate infrastructure to support the increased enrollments. Therefore, the quality of education appears to be low in Africa ${ }^{[37,24]}$ especially among countries that are facing challenges in the implementation of the Free Basic
Education.

With the evidence of reduction in quality of education due to increased enrolments and other challenges, it is advocated that, the Free Basic Education programme should be implemented with diligence and other complimentary services to achieve both the quantity and quality of education. This can be achieved by frequent policy consultation with all stakeholders. Again, with increased enrollments, governments need to develop mechanisms of maintaining quality teaching and learning in schools.

The educational stakeholders in Ghana need to revisit the drawing board to ascertain the reasons for the low primary NER as compared to the performance of Malawi, Kenya and Uganda.

There is the need for governments to give due consideration to sustainability issues. This can be done by creating additional fiscal space, so as not to throw the Free Basic Education policy overboard in the event of international financiers pulling out. Additional funding for Free Basic Education can be achieved by imposing a percentage on tax.

The study noted that, aside from the waiver of school fees, other existing challenges such as acquisition of school uniforms, text books, and feeding during school hours. Governments should make efforts in providing these items in poor communities.

The study found that, the targeting mechanism of the universal coverage was appropriate and efforts should be made to sustain it. Even though the Free Basic Education policy has its short falls, it has improved net enrolment rates in the respective countries.

\subsection{Areas for Further Studies}

This study has established that, the implementation of the Free Basic Education has increased primary school enrolments in all the four (4) countries. It is suggested that, the trend in the human capital development before and after the implementation of Free Basic Education in these countries should be assessed. This may give the true picture if indeed the Free Basic Education Policy has positively impacted human capital development aside the increases in enrollments.

\section{List of Abbreviation}

$\begin{array}{ll}\text { BGT } & : \text { Bagozzi Goal Theory } \\ \text { DFID } & : \text { Department for International Development } \\ \text { EFA } & : \text { Education for All } \\ \text { fCUBE } & : \text { free Compulsory Universal Basic Education } \\ \text { FBE } & : \text { Free Basic Education } \\ \text { NER } & : \text { Net Enrolment Rate } \\ \text { GLSS } & : \text { Ghana Living Standard Survey } \\ \text { LEAP } & : \text { Livelihood Empowerment Against Poverty } \\ \text { SGDs } & : \text { Sustainable Development Goals }\end{array}$


MoGCSP : Ministry of Gender, Children, and Social Protection

$\begin{array}{ll}\text { MOE } & \text { : Ministry of Education } \\ \text { NER } & \text { : Net Enrolment Rate } \\ \text { NGO } & \text { : Non-Governmental Organization } \\ \text { NHIS } & \text { : National Health Insurance Scheme } \\ \text { NSPS } & \text { : National Social Protection Strategy } \\ \text { OOP } & \text { : Out-Of-Pocket } \\ \text { SPF } & \text { : Social Protection Floors } \\ \text { MDGs } & \text { : Millennium Development Goals } \\ \text { GDP: } & \text { Gross Domestic Product }\end{array}$

\section{REFERENCES}

[1] Sen, A. Development as freedom. Oxford: Oxford University Press. Introduction; 1999

[2] Barrientos, A., Hulme, D. Social Protection for the Poor and Poorest in Developing Countries: Reflections on a Quiet Revolution. Oxford Development Studies, 2009; 37(4); 439-456.

[3] Cichon., M., Brendt, C., Woodsak, V. The Social Protection Floor Initiative: Moving Forward with Extension of Social Security. IPG2/2011

[4] Bachelet, M. Social protection floor (SOCPRO)-International Labour Organization. Available online

$<$ https://www.ilo.org/Secsoc/areas-of-work/social-protectio n- floor.../index.htm.

[5] Bagozzi, R., P. The Self-Regulation of Attitudes, Intentions, and Behavior. Social Psychology. 1992; 55(2): 178-204

[6] Gollwitzer, M., P. Goal Achievement: The Role of Intentions: European Review of Social Psychology.1993; 4(1):141-185

[7] Bagozzi, R., P. Dholakia, U. Goal Setting, and Goal Striving in Consumer Behaviour. Journal of marketing. 1999; 63: 19-32

[8] Gavin, J.W., Ada, L., Ulysses, J., B. A Goal-Setting and Goal-Striving Model to Better Understand and Control the Weight of U.S. Ethnic Group Members. Available at $<$ https: / www.jrconsumers.com/Academic_Articles_29/; 2007.

[9] MoGCSD. Kenya National Social Protection Policy. 2011: $1-40$

[10] Slater R., Tsoka, M. (2007) In: Chinsinga, B. The Social Protection Policy of Malawi: Processes, Politics, and Challenges. FAC Discussion Paper_002; 2007; Future Agriculture-Briefing; www.future.agriculture.org).

[11] Alderman, H., Bundy, D. School Feeding Programs and development: Are We Framing the Question Correctly?. The World Bank Research Observer. 2011; 27(2) : 204-221.

[12] Essuman A, Bosumtwi-Sam C: School Feeding and Educational Access in Rural Ghana: Is Poor Targeting and Delivery Limiting Impact? International Journal of Educational Development 2013, 33(3): 253-262
[13] Nishimura , M., Ogawa, K., Sifuna , D. N., Chimombo, J., Kunje, D., Ampiah, J. G., Byamugisha, A., .Sawamura, N. A Comparative Analysis of Universal Primary Education Policy in Ghana, Kenya, Malawi and Uganda. Journal of International Cooperation in Education, 2009; 12 (1); 143-158.

[14] Gaddah, M., Munro, A., Quartey, P. Education Subsidy and School Enrolments in Rural Areas." International Journal of Educational Development, Elsevier, 2016; 46(C); 143-152.

[15] Little W., A. Access to Basic Education in Ghana. Policies, Politics. 2010; CREATE Pathways to Access Research Monograph No. 42

[16] Rolleston, C. Educational Access and Poverty Reduction: The Case of Ghana 1991-2006. Interntional Journal of Educational Development. 2011; 31 (4); 338-349.

[17] Foster, J., Greer, J., Therbeeke, E. A Class of Decomposable Poverty Measures. Journal of Econometrics. 1984. 52(1); 761-766.

[18] Filmer, D., \& Pritchett, L. The Effect of Household Wealth on Educational Attainment: Evidence from 35 countries. Population and Development Review. 1999: 25(1); 85-120

[19] Canagarah, S., \& Portner, C. Evolution of poverty and Welfare in Ghana in the 1990s: Achievements and Challenges. Accra: World Bank. 2004.

[20] Osei, R. D., Quarmine, I., \& Adayi-Nwoa, G., A. Public Spending in Ghana; An Assessment of National Level Data (1995-2005). Ghana Strategy Support Programme (GSSP) Washington, DC: International Food Policy Research Institute (IFPRI). 2007; Background Paper No. GSSP 0004.

[21] Perran, P., Cost Sharing in Education-Public Finance, School and Household Perspective. DFiD. Education Research Paper. 1998; No.27. 141

[22] United Nation Development Programme. Expenditure on Education; Public, World Bank. 2013.

[23] Reinikka, R., \& Svensson, J. Local Capture: Evidence from a Central Government Transfer Program in Uganda. Quarterly Journal of Economics. 2004; 119(2); 679-705.

[24] Akyeampong, K., J. Djangmah, A. Seidu, A. Oduro, and F. Hunt. Access to Basic Education in Ghana: The Evidence and the Issues. CREATE Country Analytic Report. Sussex: CREATE, 2007.

[25] Awoyemi, T. T., Obayelu, O. A., \& Opaluwa, H. I. Effect of Distance on Utilization of Health Care Services in Rural Kogi State, Nigeria. Journal of Human Ecology; 2011; 35(1), $1-9$.

[26] Create. Public and Private Schooling in Rural Ghana: Are the poor being served?. Ghana: Consortium for Research on Educational Access, Transitions and Equity. Create Ghana policy brief $3 ; 2010$.

[27] Nudzor, P. H. Unmasking Complexities involved in Operationalising UPE Policy Initiatives: The "fCUBE' policy implementation in Ghana as an exemplar. Journal of Educational Change. 2012; 13(3); 347-371.

[28] UNAIDS. 2014. 90-90-90. An ambitious treatment target to help end the AIDS epidemic. Available: http://www.unaids.org/sites/default/files/media_asset/90-90 -90_en_0.pdf. 
[29] MoCGSP. Ghana National Social Protection Policy. 2007; 2015.: 1-63

[30] Acheampong, K., Revisiting Free Compulsory Universal Basic Education (fCUBE) in Ghana. Journal of Comparative Education; 2009; 45(2)

[31] Knoema. World Class Data. 2016; Available at $<$ https.//knoema.com>

[32] Ministry of Education. Annual Education Statistics (2016). Malawi

[33] Ministry of Education, 2014, Kenya.

[34] JICA. Basic Education Sector Analysis Report
(2012).Kenya

[35] World Bank Study on Primary Education in Malawi (Expenditure, Services Delivery, and Outcomes, 2016.

[36] Abdul, M. I., Danquah, M., Quartey, P. Analysis of School Enrolment in Ghana: A Sequential Approach. International Research Conference on Multi-disciplinary Research and Transformation in Africa. University of Ghana. 2015; 1.

[37] Asante C. The Capitation Grant: Impact on Enrolment of Pupils in the Basic Education Schools in Ghana. A case Study of JHS in Sunyani Municipality. 2011; < Available Online >http://ir.knust.edu.gh/xmlui/handle/123456789/427 $0 /$

\footnotetext{
i Joseph Kwasi Brenyah is a PhD Candidate at University of Ghana offering Ph.D Social Policy Studies and currently on Exchange Program with Department of Social Work, University of Wyoming, USA. His research interests are in social protection, vulnerabilities, poverty dynamics and Health. All correspondences should be directed to bresjosaf@gmail.com/ jkbrenyah@st.ug.edu.gh. His contact numbers are +233 206662866/ +233 $244527746 /+13077613914$
} 